\title{
СРАВНИТЕЛЬНАЯ ОЦЕНКА ПРИРОДНЫХ КОРМОВЫХ ДОБАВОК ПО ФУНКЦИОНАЛЬНОМУ ДЕЙСТВИЮ НА ПРОЦЕССЫ ПИЩЕВАРЕНИЯ И МИКРОБИОТУ РУБЦА У ОВЕЦ (Ovis aries)
}

\section{Ю.П. ФОМИЧЕВ, Н.В. БОГОЛЮБОВА, В.Н. РОМАНОВ, Е.Н. КОЛОДИНА}

С целью создания в рубце оптимальной среды для жизнедеятельности микроорганизмов и переваривания различных кормовых субстратов рациона в практике кормления жвачных животных применяют эрготропики, грибные культуры, модификаторы, антиоксиданты, ферменты и другие кормовые добавки с различными биологическими свойствами. В настоящем исследовании мы впервые установили особенности и степень проявления биологических свойств природных кормовых компонентов в отношении пищеварительных процессов и микробиоты в рубце овец, что позволит повысить эффективность конверсии корма с помощью таких добавок и профилактировать метаболическое и клиническое здоровье овец. Целью работы было изучение характера влияния кормовых добавок с различными биологическими свойствами на ферментативные процессы и микробиоту рубца у овец. Исследования проводили в условиях физиологического двора Всероссийского НИИ животноводства им. Л.К. Эрнста на овцах (Ovis aries) романовской породы. В 2014 году (первый цикл экспериментов) из животных в возрасте 4-5 мес методом аналогов сформировали четыре группы (по $n=3$ в каждой). Животные контрольной группы получали основной рацион (OP), овцы опытных групп вместе с ОР - минерал шунгит $(0,3 ; 0,9$ и $1,5 \%$ от сухого вещества ОР). В 2018-2019 годах выполняли эксперименты на 6 фистулированных овцах в возрасте 2 лет методом групп-периодов (два цикла, в каждом - контрольный и два опытных периода продолжительностью по 14 сут с подготовительным 14-суточным интервалом перед каждым из трех указанных периодов). В первом из циклов в контрольный период овцы получали ОР, в 1-й опытный период к ОР добавляли дигидрокверцитин (ДКВ) $\left(100\right.$ мг гол $^{-1} \cdot$ сут $\left.^{-1}\right)+$ органический йод (OI) $\left(1,05\right.$ мг гол ${ }^{-1} \cdot$ сут $\left.^{-1}\right)$, во 2-й опытный период - только ДКВ (100 мг гол ${ }^{-1} \cdot$ сут $\left.^{-1}\right)$. В следующем цикле в 1-й опытный период к ОР добавляли мицеллат кальция (М-Са) в форме рабочего раствора, который вводили непосредственно в рубец через фистулу (50 мкл• гол ${ }^{-1} \cdot$ сут $\left.^{-1}\right)$, во 2 -й опытный период - спирулину (сухой порошок) $\left(1,25\right.$ г гол $^{-1} \cdot$ сут $\left.^{-1}\right)$ в смеси с 23,75 г наполнителя. Во всех циклах конце каждого периода через 3 ч после кормления отбирали пробы рубцового содержимого, в котором определяли рН, окислительно-восстановительный потенциал (ОВП), окисленность, общее количество летучих жирных кислот (ЛЖК), концентрацию аммиачного азота, амилолитическую активность, биомассу простейших и бактерий, видовой состав микроорганизмов и их основные групाы. Установлено, что по действию на рН содержимого рубца наиболее эффективны ДКВ и спирулина. При их добавлении к ОР рН химуса повысился соответственно на 12,7 и 9,5\%. По влиянию на образование ЛЖК наиболее эффективными были шунгит при всех дозировках и М-Са. При их включении в рацион увеличение содержания ЛЖК в химусе составило 20,$6 ; 27,2(p<0,05), 22,8$ и 6,6 \%. Действие ДКВ + ОІ, ДКВ и спирулины на содержание ЛЖК в химусе было негативным $(93,5,81,2$ и 81,8 \% от показателя в контрольный период). Применение изучаемых КД, за исключением ДКВ + ОІ, привело к уменышению количества аммиака в химусе: наиболее заметное - на $24,1(p<0,01)$ и $26,3 \%$ - происходило под влиянием ДКВ и М-Са. Шунгит тоже уменышал содержание аммиака в химусе - по группам соответственно на $18,6(\mathbf{p}<0,05), 12,6$ $(p<0,05)$ и 8,5 \% по отношению к контролю. Сочетание ДКВ + ОІ, напротив, приводило к росту этого показателя на 16,5 \%. Повышение амилолитической активности химуса на 6,$1 ; 1,7$ и $1,1 \%$ отмечалось при применении соответственно спирулины, М-Са и сочетания ДКВ + ОІ. Под действием шунгита амилолитическая активность значительно снижалась (на 16,8-19,9 \%), под влиянием ДКВ снижение было минимальным $(7,3$ \%). Состояние ферментативных процессов отразилось на количественном и видовом составе микробиоты. Наиболыший эффект в накоплении микробной массы в химусе был получен при включении в рацион шунгита и зависел от дозировки минерала. Шунгит способствовал повышению общей численности микроорганизмов - по группам соответственно в 2 раза $($ p $<0,01)$, на $47,4 \%(p<0,05)$ и $25,2 \%$ (в основном за счет инфузорий) - и изменению соотношения между процентом инфузорий и бактерий. ДКВ + ОI, ДКВ и МСа при добавлении к ОР также увеличивали микробиальную массу в химусе, но в значительно меньшей степени, чем шунгит, - соответственно на 14,6; 2,2 и 1,8 \% по отношению к контролю. Под действием спирулины общее обилие микроорганизмов снижалось на $14,3 \%$. При анализе влияния различных КД на микробиоценоз рубца прослеживалась положительная связь с индексом соотношения аммиак/ЛЖК, который может характеризовать степень конверсии корма в микробный протеин.

Ключевые слова: кормовые добавки, шунгит, дигидрокверцитин, органический йод,

* Работа выполнена при финансовой поддержке фундаментальных научных исследований Минобрнауки России, номер государственного учета НИОКТР АААА-А18-118021590136-7. 
спирулина, романовские овцы, рубец, ферментация, химус, амилаза, летучие жирные кислоты, аммиак, микробиота.

Рубец играет первостепенную роль в пищеварительной системе жвачных. В этой камере сложного желудка за счет микробиологической ферментации удовлетворяется до 80 \% потребности в энергии, 30-50 \% - в белке, в значительной степени - в макро- и микроэлементах и витаминах, а также переваривается до 70 \% сырой клетчатки. Существует связь между химическим составом и питательностью кормового субстрата, численностью микроорганизмов рубца и продуктивностью животных $(1,2)$. Значительный стимулирующий эффект в отношении роста и размножение микрофлоры оказывают субстраты с высоким содержанием азота, протеина, жира, безазотистых экстрактивных веществ. Оптимальными для размножения микроорганизмов рубца считаются уксуснокислый тип брожения и рН среды ближе к нейтральным значениям (рН 6,6-6,9). К менее благоприятным условиям относятся пропионово-масляный тип брожения и рН среды от 6,2 до 6,5. Наибольшая дополнительная нагрузка по нейтрализации рубцового содержимого в последнем случае ложиться на слюнные железы (3, 4). В практике кормления с целью создания в рубце оптимальной среды для жизнедеятельности микроорганизмов и переваривания различных кормовых субстратов рациона применяют эрготропики, грибные культуры, модификаторы, антиоксиданты, ферменты и другие кормовые добавки с различными биологическими свойствами (5-7). Предпочтение отдается природным биологически активным веществам как альтернативе применению антибиотиков (8-10).

Дигидрокверцитин (ДКВ), который получают из лиственницы даурской (Larix dahurica Turez), участвует в регуляции метаболических процессов, положительно влияет на функциональное состояние внутренних органов, создает механизмы защиты здоровых клеток организма от патологий. ДКВ широко применяется в медицине, пищевой промышленности и других отраслях народного хозяйства (11). По запросу Европейской комиссии (European Commission, EC) группой ученых по диетическим продуктам и питанию была проведена оценка и показана безопасность использования экстракта из лиственницы даурской, богатого дигидрокверцетином (таксифолином), как пищевого ингредиента согласно Regulation (EC) No 258/97 of the European Parliament and of the Council of 27 January 1997 concerning novel foods and novel food ingredients. Дигидрокверцетин применяли в форме кормовой добавки Экостимул 2 (АО «Аметис», Россия), содержащей до $88 \%$ дигидрокверцетина и около $10 \%$ сопутствующих биофлавоноидов (12).

На основе органического йода (OI) создана кормовая добавка (КД) Прост (ООО «ИнБиоТех», Россия), представляющая собой смесь полноценных белков сыворотки молока, которые содержат 2,5 \% ковалентно связанных атомов йода. Благодаря ковалентной связи с белками биойод обладает высокой стабильностью (выдерживает нагревание до $300{ }^{\circ} \mathrm{C}$, устойчив к свету и при длительном хранении). Йод входит в состав тиреодиных гормонов в форме йодированные производные остатков L-тирозина. Физиологическое действие тиреоидных гормонов связано с регуляцией интенсивности дыхания клеток, непосредственным влиянием на поглощение кислорода митохондриями и другими клеточными компартментами, усилением окислительных реакций и основного обмена в организме. Тиреоидные гормоны оказывают значительное воздействие на активность ферментов и генный аппарат клеток, на морфогенез и воспроизводительную функцию (13, 14). Скармливание органического йода мелким жвачным способствовало 
значительному увеличению живой массы и среднесуточного прироста, что может быть связано с высокой концентрацией тироксина (13). Процессы органификации йода происходят в щитовидной железе, в молочной и слюнных железах, в других тканях и органах. Известно, что около 90 \% йода, содержащегося в рационах животных, накапливается в щитовидной железе в виде йодидов. Последние окисляются до йода с участием перекиси водорода, что катализируется пероксидазой щитовидной железы. Предварительные исследования показали, что совместное скармливание антиоксидантов с органическим йодом способствовало, с одной стороны, повышению активности глутатионпероксидазы, исправляя дисбаланс окислительной и антиоксидантной систем, с другой - регуляции функции щитовидной железы $(14,15)$.

Мицеллат углекислого кальция (М-Ca) - комплексный препарат в форме суспензии, содержащий в качестве основного компонента карбонат кальция и служащий одним из регуляторов его обмена в организме. При поступлении в желудочно-кишечный тракт коллоидного раствора $\mathrm{M}-\mathrm{Ca}$ он нейтрализуется соляной кислотой с образованием ионов кальция (восполнению дефицита кальция способствует только его ионизированная форма), а также активных форм кислорода (АФК). АФК формируются в небольшом количестве в водной среде, их концентрация не выходит за рамки физиологической нормы. АФК способствуют образованию свободных электронов. Внесение М-Са в воду инициирует электронную активацию, что приводит к коррекции нарушений, вызванных различными патологическими факторами. При этом нормализуется работа системы окислительного фосфорилирования и повышается антиоксидантный статус клеток $(16,17)$. Как результат, восстанавливаются ранее ослабленные функции органов и тканей, в том числе ответственные за костное ремоделирование и регенерацию поврежденных костей: замедляются деструктивные процессы в костной ткани, изменяется соотношение регуляторов остеокластогенеза в сторону их сбалансированности, стимулируется регенерация эпителиальной ткани, улучшается периферическая микроциркуляция (18-20).

Микроводоросль спирулина (Spirulina platensis) содержит абсолютно все вещества, которые необходимы человеку и животным для нормальной жизнедеятельности $(21,22)$, а также обладает широким спектром биологической активности: стимулирует обмен веществ, укрепляет костяк, нормализует состояние кожно-волосяного покрова и слизистых оболочек, нейтрализует токсины, улучшает функции пищеварительной системы, в конечном итоге способствуя повышению продуктивности и устойчивость животных к различным заболеваниям $(23,24)$. Показано, что этот продукт служит ценным кормовым средством для многих видов животных. Скармливание спирулины приводит к увеличению количественного и качественного состава лактобацилл в кишечнике, поддержанию высокого содержания гемоглобина и эритроцитов в крови, повышению скорости роста, плодовитости животных и качества пищевых продуктов. Ученые связывают положительное влияние спирулины с богатым набором биологически активных веществ и уникальным белковым составом $(25,26)$.

Шунгит - природный минерал, необычный по происхождению, структуре входящего в его состав углерода и структуре самих пород $(27,28)$. Основу шунгитового углерода (содержание в минерале - $30 \%$ ) составляет многослойная глобула размером около 10 нм. Такая структура очень активна в окислительно-восстановительных реакциях, обладает сорбционными и каталитическими свойствами. Окиси макро- и микроэлементов 
(всего более 20) составляют 70 \% минерала и в основном представлены соединениями кремния. Минеральная часть шунгита обладает адсорбционными, связывающими, буферными и ионообменными свойствами. Окиси кремния способствуют повышению усвоения макро- и микроэлементов, влияют на показатели естественной резистентности животных, метаболизм витаминов и биологически активных веществ. Фуллерены в составе шунгита повышают устойчивость мембран клеток к повреждающим факторам, обладают антиоксидантными и радиопротекторными свойствами за счет подавления избыточного образования свободных радикалов, оказывают положительное действие на энергетические системы организма $(29,30)$. По мнению ученых, антиоксидантные свойства фуллеренов заключаются в инактивации активных форм кислорода, в частности гидроксильных радикалов, за счет присоединения их по многочисленным двойным связям, накоплению в митохондриях, снижению трансмембранного потенциала (31). Изучение биологических эффектов шунгита и его производных в биомедицине и ветеринарии остается актуальным $(32,33)$. В исследованиях на сельскохозяйственных животных и птице отечественными и зарубежными учеными установлена высокая эффективность применения шунгита, не обладающего кумулятивным, аллергизирующим, эмбриотоксическим, тератогенным действием, не оказывающего раздражающего эффекта на слизистые оболочки и отрицательного влияния на функциональную деятельность печени $(32,34)$.

Таким образом, многие положительные эффекты описанных кормовых факторов известны и нашли практическое применение. Однако современное понимание того, как они действуют на ферментативные и микробиологические системы рубца, ограничено.

В настоящем исследовании мы впервые установили особенности и степень влияния перечисленных природных кормовых компонентов на активность ферментов и микробиоту рубца овец, что позволяет улучшать конверсию корма при включение этих добавок в рацион и профилактировать метаболическое и клиническое здоровье животных.

Целью работы была оценка воздействия биоактивных кормовых добавок с различными свойствами на состояние процессов пищеварения и микробиоту рубца у овец.

Методика. Исследования проводили в условиях физиологического двора Всероссийского НИИ животноводства им. Л.К. Эрнста на овцах (Ovis aries) романовской породы.

Первый цикл экспериментов (2014 год) выполняли на животных в возрасте 4-5 мес. Методом аналогов сформировали четыре группы по три особи в каждой. Животные контрольной группы получали основной рацион (OР), состоящий из 2 кг кормосмеси и 0,35 кг концентратов, с общей питательностью 9 МДж ОЭ (0,9 ЭКЕ). Овцы опытных групп вместе с ОР получали природный минерал шунгит (Зажогинское месторождение, Республика Карелия, ООО НПК «Карбон-шунгит», Россия) в количестве 0,3; 0,9 и $1,5 \%$ от сухого вещества ОР.

В 2018-2019 годах два цикла экспериментов проводили на шести фистулированных овцах в возрасте 2 лет методом групп-периодов - одного контрольного и двух опытных продолжительностью 14 сут каждый (каждому из трех периодов предшествовал 14-суточный перерыв для выравнивания состояния животных). В обоих циклах в контрольный период овцы получали ОР, состоящий из 1,5 кг сена и 0,4 кг концентратов (общая питательность 13,2 МДж ОЭ = 1,32 ЭКЕ) с содержанием 180 г протеина, 40 г жира, 380 г клетчатки. В первом цикле в 1-й опытный период к ОР 
добавляли ДКВ $\left(100 \mathrm{мг} \cdot\right.$ гол $^{-1} \cdot$ сут $\left.^{-1}\right)+$ OI $\left(1,05\right.$ мг $\cdot$ гол $^{-1} \cdot$ сут $\left.^{-1}\right)$, во 2-й опытный период - ДКВ (100 мг $\cdot$ гол $^{-1} \cdot$ сут $\left.^{-1}\right)$. Биологически активные вещества давали овцам в опытные периоды в форме смесей (по 10 $\Gamma \cdot$ гол $^{-1} \cdot$ сут $\left.^{-1}\right)$. В 1-й опытный период смесь состояла из наполнителя (сухие размолоченные ростки), КД Экостимул-2 (АО «Аметис», Россия) (ДКВ $80 \%)$ и КД Прост (ООО «ИнБиоТех», Россия) (7 мг йода/г), во 2-й опытный период - из наполнителя и КД Экостимул-2. Во втором цикле в 1-й и 2-й опытные периоды к ОР добавляли соответственно М-Са в форме рабочего раствора (ЗАО «Петрохим», Россия), который вводили непосредственно в рубец через фистулу $\left(50\right.$ мкл $\cdot$ гол $^{-1} \cdot$ сут $\left.^{-1}\right)$, и спирулину в виде сухого порошка (ООО «Биосоляр МГУ») $\left(1,25\right.$ г $•$ гол $^{-1} \cdot$ сут $\left.^{-1}\right)$ в смеси с 23,75 г наполнителя.

Во всех циклах экспериментов в конце каждого периода через 3 ч после кормления отбирали пробы рубцового содержимого, в котором определяли рН (приборе Аквилон 420, АО «Аквилон», Россия), окислительновосстановительный потенциал (ОВП) - с помощью ОВП-метра ORP-2069 («YIERYI», Китай), окисленность - по реакции с тиобарбитуровой кислотой. Общее количество летучих жирных кислот оценивали методом паровой дистилляции в аппарате Маркгама, концентрацию аммиачного азота микродиффузным методом по Конвею, амилолитическую активность - фотометрически (спектрофотометр КФК-3-01, «ЗОМЗ», Россия). Биомассу простейших и бактерий в рубцовом содержимом определяли методом дифференциальное центрифугирования (J2-21, «Beckman Coulter GmbH», Германия), видовой состав микроорганизмов и их основные группы (молочнокислые, кишечной палочки, энтерококков, общее количество) - методом высева серийных (10-кратных) разведений на накопительные и дифференциально-диагностические среды (ФБУН ГНЦ ПМБ, г. Оболенск, Россия; «HiMedia Laboratories Pvt. Ltd», Индия) глубинным и поверхностным способом с последующим подсчетом числа микроорганизмов (KOЕ/г) по группам.

Биометрическую обработку осуществляли с использованием метода дисперсионного анализа (ANOVA) в программе STATISTICA 10 («StatSoft, Inc.», США). Вычисляли среднеарифметические значения (M), стандартную ошибку среднего ( $\pm \mathrm{SEM})$, для оценки уровня значимости $(\mathrm{p})$ использовали $t$-критерий Стьюдента.

Результаты. Интенсивность и направленность процессов пищеварения в рубце жвачных, а следовательно, и эффективность использования корма, тесно связаны с составом водной среды химуса, которая определяется рН и ОВП и зависит от структуры и питательности рациона, качества питьевой воды, интенсивности секреции у слюнных желез, состояния микробиоценоза. С повышением ОВП воды улучшаются ее биоэнергетические, метаболические и иммуностимулирующие свойств, что обеспечивает благоприятные условия для развития микроорганизмов $(16,17)$.

Добавление к рациону овец ДКВ отдельно и совместно с органическим йодом оказало значительное влияние на физико-химические свойства химуса рубца, ферментативные и микробиологические процессы. В

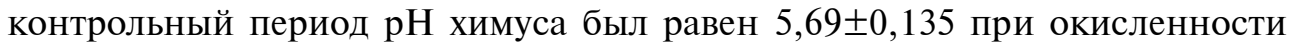

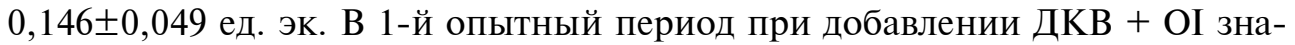
чение $\mathrm{pH}$ химуса повысилось до $5,85 \pm 0,078$ на фоне значительного (в 2,8 раза) увеличения его окисленности $(\mathrm{p}<0,01)$. Во 2-й опытный период под действием ДКВ величина $\mathrm{pH}$ химуса достигала $6,41 \pm 0,053$ при снижении окисленности в 1,80 и 5,08 раза по отношению к контрольному и 1-му опытному периоду ( $<0,05)$ (табл. 1). 
Значения ОВП химуса показали, что включение ОІ в рацион овец приводило к усилению окислительных процессов, в то время как ДКВ, наоборот, усиливал восстановительные процессы (см. табл. 1). Это согласуется с данными по окисленности и рН химуса и служит характерным проявлением окислительных свойств йода и восстановительных - дигидрокверцетина как антиоксиданта.

Амилолитическая активность химуса определяется микроорганизмами, для которых наиболее благоприятна кислая среда с $\mathrm{pH}$ 5,4-6,2. В наших исследованиях рН химуса в контрольный и 1-й опытный период (ДКВ+ОI) были близки, что определило и сходную амилолитическую активность (см. табл. 1). Повышение $\mathrm{pH}$ химуса во 2-й опытный период (при использовании только ДКВ) привело к снижению амилолитической актив-

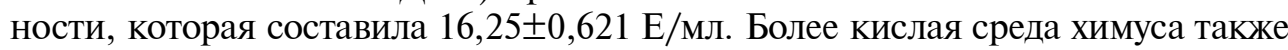
благоприятна для жизнедеятельности микроорганизмов, сбраживающих сахара с образованием молочной, уксусной, пропионовой и масляной кислот, которые почти полностью всасываются в преджелудках. В связи с этим количество летучих жирных кислот (ЛЖК) в химусе у овец в контрольный и 1-й опытный (ДКВ+ОI) периоды было близким и составило соответственно $11,84 \pm 0,325$ и $11,07 \pm 0,226$ ммоль/100 мл. Во 2-й опытный период (ДКВ) при включении в рацион антиоксиданта рН химуса повысился, что могло повлиять на видовой состав микрофлоры и процессы брожения, в результате чего содержание ЛЖК в химусе в этот период снизилось на 18,83 \% $(\mathrm{p}<0,05)$ (см. табл. 1).

1. Физиолого-биохимические и микробиологические показатели химуса рубца у овец (Ovis aries) романовской породы при включении в рацион дигидрокверцитина (ДКВ) и органического йода (OI) $(n=6, M \pm \mathrm{SEM}$, ФГБНУ ФНЦ ВИЖ им. Л.К. Эрнста, 2018-2019 годы)

\begin{tabular}{|c|c|c|c|}
\hline \multirow[b]{2}{*}{ Показатель } & \multicolumn{3}{|c|}{ Период } \\
\hline & контрольный & $\begin{array}{c}\text { 1-й опытный } \\
\text { (ДКВ+OI) }\end{array}$ & $\begin{array}{c}\text { 2-й опытный } \\
\text { (ДКВ) }\end{array}$ \\
\hline $\mathrm{pH}$ & $5,69 \pm 0,135$ & $5,85 \pm 0,078$ & $6,41 \pm 0,053^{* * / \epsilon \epsilon}$ \\
\hline Окисленность, ед. экс. & $0,15 \pm 0,049$ & $0,41 \pm 0,032^{* *}$ & $0,08 \pm 0,003^{\epsilon \epsilon}$ \\
\hline ОВП, мВ & $-272 \pm 15,9$ & $+107 \pm 10,27^{* * *}$ & $-404 \pm 7,78^{* * * / \epsilon є \epsilon ~}$ \\
\hline ЛЖК, ммоль/100 мл & $11,84 \pm 0,325$ & $11,07 \pm 0,226$ & $9,61 \pm 0,613^{*}$ \\
\hline Аммиак, мг\% & $17,42 \pm 2,777$ & $20,31 \pm 1,171$ & $13,23 \pm 1,892^{\epsilon \epsilon}$ \\
\hline Аммиак/ЛЖК & 1,47 & 1,83 & 1,37 \\
\hline Амилолитическая активность, Е/мл & $17,52 \pm 0,249$ & $17,72 \pm 0,324$ & $16,25 \pm 0,621$ \\
\hline $\begin{array}{l}\text { Микроорганизмы, г/100 мл: } \\
\text { всего } \\
\text { в том числе }\end{array}$ & $0,89 \pm 0,059$ & $1,02 \pm 0,064$ & $0,91 \pm 0,040$ \\
\hline $\begin{array}{l}\text { инфузории, г/100 мл } \\
\text { инфузории, \% } \\
\text { бактерии, г/100 мл } \\
\text { бактерии, \% }\end{array}$ & $\begin{array}{c}0,36 \pm 0,040 \\
40,3 \\
0,53 \pm 0,024 \\
59,7\end{array}$ & $\begin{array}{c}0,45 \pm 0,031 \\
43,6 \\
0,57 \pm 0,053 \\
56,4\end{array}$ & $\begin{array}{l}0,26 \pm 0,024^{* / \epsilon \epsilon} \\
28,6 \\
0,65 \pm 0,033^{*} \\
71,4\end{array}$ \\
\hline $\begin{array}{l}\text { П р и м е ч а н и е. ОВП - окислите } \\
\text { Подробное описание опытных пери } \\
*, * *, * * * \text { Различия между показател } \\
\text { чимы соответственно при } \mathrm{p}<0,05 ; \\
\epsilon, \text { єє, єєє Различия между показателя } \\
\text { ственно при } \mathrm{p}<0,05 ; \mathrm{p}<0,01 \text { и }<<\end{array}$ & $\begin{array}{l}\text { восстановительн } \\
\text { см. в разделе «М } \\
\text { в опытные перис } \\
01 \text { и р }<0,001 . \\
2 \text {-й и в } 1-\text { й оп }\end{array}$ & $\begin{array}{l}\text { отенциал, ЛЖК } \\
\text { ва». } \\
\text { в контрольный } \\
\text { е периоды стати }\end{array}$ & $\begin{array}{l}\text { ие жирные кислоты. } \\
\text { статистически зна- } \\
\text { и значимы соответ- }\end{array}$ \\
\hline
\end{tabular}

Значительные различия по периодам опыта наблюдались в содержании в химусе аммиака, численности инфузорий и бактерий, что было связано со специфическими свойствами применяемых биологически активных веществ (ДВК и ОI). Содержание аммиака в химусе повышалось в 1-й опытный период относительно контрольного на 16,6 \% и снижалось во 2-й опытный период на 24,1\% (p < 0,01), что может быть связано с интенсивностью его использования в микробиологическом синтезе белка. Это подтверждают и изменения в количественном и видовом составе микроорганизмов химуса. 
Общее количество микроорганизмов в контрольный период составило

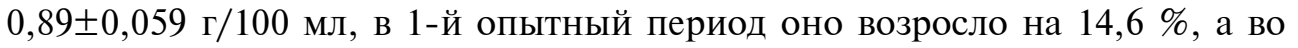
2-й - на 2,2 \%. При этом менялось и их видовое соотношение. В контрольный период процентное соотношение инфузорий и бактерий составило 40,3:59,7, в 1-й опытный период - 43,6:56,4, во 2-й - 28,6:71,4. В результате по отношению к контрольному в 1-й опытный период количество инфузорий увеличилось на 25,0 \%, бактерий - на 7,5 \%, во 2-й опытный период количество инфузорий снизилось на $27,8 \%(\mathrm{p}<0,05)$, а бактерий - увеличилось на $22,6 \%(\mathrm{p}<0,05)$ (см. табл. 1$)$.

Изучаемые биологически активные вещества (ДКВ с ОI) значительно повлияли на состав микробиоты рубца. Под их совместным действием в содержимом рубца количество лактобацилл увеличилось в 10 раз, под действием ДКВ - в 11,5 раза. Во 2-й опытный период по отношению к 1-му численность лактобацилл возросла в 10 раз (табл. 2). Значительную группу микроорганизмов в желудочно-кишечном тракте представляют мезофильные аэробные и факультативно анаэробные. Дигидрокверцетин в сочетании с йодом и отдельно оказали специфическое влияние на количество мезофильных аэробных и факультативно анаэробных микроорганизмов (КМАФАнМ), кишечную палочку, грибы рода Candida, плесени и дрожжи в содержимом преджелудков. В 1-й опытный период КМАФАнМ увеличилось в 4 раза по отношению к контрольному, во 2-й - в 21 раз. Количество грибов рода Candida, плесеней и дрожжей по отношению к контрольному периоду в 1-й опытный снизилось в 3,6 раза, во 2-й - повысилось в 1,8 раза. В этот же период по отношению к 1-му количество указанных микроорганизмов было больше в 6,4 раза (см. табл. 2.). Кроме того, в содержимом рубца были выявлены Bacillus spp. и не обнаруживались клостридии и лактозоотрицательная кишечная палочка во всех периоды исследования (см. табл. 2).

2. Состав микробиоценоза (КОЕ/мЛ) рубца у овец (Ovis aries) романовской породы при включении в рацион дигидрокверцитина (ДКВ) и органического йода (OI) $(n=6, M \pm$ SEM, ФГБНУ ФНЦ ВИЖ им. Л.К. Эрнста, 2018-2019 годы)

\begin{tabular}{|c|c|c|c|}
\hline \multirow[b]{2}{*}{ Показатель } & \multicolumn{3}{|c|}{ Период } \\
\hline & контрольный & $\begin{array}{c}\text { 1-й опытный } \\
\text { (ДКВ+OІ) }\end{array}$ & $\begin{array}{c}\text { 2-й опытный } \\
\text { (ДКВ) }\end{array}$ \\
\hline Лактобактерии & $5,6 \times 10^{3} \pm 2,90 \times 10^{3}$ & $5,6 \times 10^{4} \pm 2,20 \times 10^{4}$ & $6,4 \times 10^{4} \pm 2,70 \times 10^{3}$ \\
\hline \multicolumn{4}{|l|}{ Споровые микроорганизмы: } \\
\hline Bacillus spp. & Обнаружены & Обнаружены & Обнаружены \\
\hline клостридии & Не обнаружены & Не обнаружены & Не обнаружены \\
\hline МАФАнМ & $1,2 \times 10^{3} \pm 1,10 \times 10^{2}$ & $4,9 \times 10^{3} \pm 1,12 \times 10^{3}$ & $2,6 \times 10^{4} \pm 8,75 \times 10^{3}$ \\
\hline \multicolumn{4}{|l|}{ Кишечная палочка: } \\
\hline лактозоположительная & $6,8 \times 10^{3} \pm 5,98 \times 10^{3}$ & $0,8 \times 10^{1} \pm 0,74 \times 10^{1}$ & $5,3 \times 10^{2} \pm 1,42 \times 10^{2}$ \\
\hline лактозоотритцательная & Не обнаружены & Не обнаружены & Не обнаружены \\
\hline $\begin{array}{l}\text { Грибы рода Candida, плесени и } \\
\text { дрожжи }\end{array}$ & $2,7 \times 10^{2} \pm 5,98 \times 10^{1}$ & $7,5 \times 10^{1} \pm 0,74 \times 10^{1}$ & $4,8 \times 10^{2} \pm 1,42 \times 10^{2}$ \\
\hline $\begin{array}{l}\text { П р и м е ч а н и е. МАФАнМ - } \\
\text { Подробное описание опытных п }\end{array}$ & $\begin{array}{l}\text { мезофильные аэробные } \\
\text { риодов см. в разделе «М }\end{array}$ & $\begin{array}{l}\text { и факультативно аназ } \\
\text { Методика». }\end{array}$ & ные микроорганизмы. \\
\hline
\end{tabular}

Различия в элиминирующем действии ДКВ + ОI и ДКВ на различные микроорганизмы, по всей видимости, связаны в первом случае с антисептическими свойствами йода, во втором - с избирательными свойствами ДКВ по отношению к различным штаммам микроорганизмов. Дигидрокверцетин обладает сильными бактерицидными свойствами, тормозящими гнилостные процессы, что дает основание считать его природным аналогом антибиотиков (9).

При включении в рацион овец М-Са и спирулины также проявились положительные тенденции. Изменялись кислотно-щелочное равновесие, ферментативная активность и состояние микробиоты химуса. Под 
действием М-Са и спирулины $\mathrm{pH}$ химуса повысился соответственно на 3,6 и 9,5\% при одновременном снижении его окисленности на 2,4 и 19,5\% в сочетании с уменьшением значений восстановительного потенциала (табл. 3). Присутствие в химусе М-Са повысило образование ЛЖК и амилолитическую активность соответственно на 6,6 и 1,7 \% при снижении содержания аммиака на 26,3 \% и индексе аммиак/ЛЖК 1,46, что свидетельствует о лучшем использовании аммиака микробиотой.

3. Физиолого-биохимические и микробиологические показатели химуса рубца у овец (Ovis aries) романовской породы при включении в рацион мицеллата кальция (M-Ca) и спирулины $(n=6, M \pm \mathrm{SEM}$, ФГБНУ ФНЦ ВИЖ им. Л.К. Эрнста, 2018-2019 годы)

\begin{tabular}{|c|c|c|c|}
\hline \multirow[b]{2}{*}{ Показатель } & \multicolumn{3}{|c|}{ Период } \\
\hline & контрольный & $\begin{array}{c}\text { 1-й опытный } \\
\text { (M-Ca) }\end{array}$ & $\begin{array}{c}\text { 2-й опытный } \\
\text { (спирулина) }\end{array}$ \\
\hline $\mathrm{pH}$ & $6,31 \pm 0,107$ & $6,54 \pm 0,137$ & $6,91 \pm 0,111$ \\
\hline Окисленность, ед. экс. & $0,41 \pm 0,050$ & $0,40 \pm 0,018$ & $0,33 \pm 0,009$ \\
\hline ОВП, мВ & $-282 \pm 10,7$ & $-237 \pm 13,1$ & $-261 \pm 14,9$ \\
\hline ЛЖК, ммоль/100 мл & $8,59 \pm 0,489$ & $9,16 \pm 0,355$ & $7,03 \pm 0,197$ \\
\hline Аммиак, мг\% & $18,19 \pm 0,552$ & $13,40 \pm 1,047$ & $17,57 \pm 1,608$ \\
\hline Аммиак/ЛЖК & 2,11 & 1,46 & 2,49 \\
\hline Амилолитическая активность, Е/мл & $16,70 \pm 0,448$ & $16,99 \pm 0,160$ & $17,72 \pm 0,483$ \\
\hline \multicolumn{4}{|l|}{ Микроорганизмы, г/100 мл: } \\
\hline всего & $1,12 \pm 0,083$ & $1,14 \pm 0,147$ & $0,96 \pm 0,113$ \\
\hline \multicolumn{4}{|l|}{ в том числе } \\
\hline инфузории, г/100 мл & $0,58 \pm 0,053$ & $0,58 \pm 0,096$ & $0,47 \pm 0,060$ \\
\hline инфузории, \% & 51,3 & 50,9 & 48,2 \\
\hline бактерии, г/100 мл & $0,55 \pm 0,064$ & $0,56 \pm 0,096$ & $0,50 \pm 0,055$ \\
\hline бактерии, \% & 48,7 & 49,1 & 51,8 \\
\hline
\end{tabular}

При добавлении спирулины к рациону наблюдалось уменьшение содержания ЛЖК на 18,2 \% при незначительном повышении амилолитической активности и уменьшении количества аммиака по отношению к контрольному периоду, что сказалось на состоянии микробиоты (см. табл. 3). Общее количество микроорганизмов в химусе снизилось по сравнению с контрольным периодом на 14,3\%, в том числе инфузорий - на 19,0\%, бактерий - на 9,1 \%. Такой характер влияния спирулины на пищеварение в рубце, возможно, связан с недостаточным содержанием энергии в рационе. Так, у молочных коров черно-пестрой породы добавление к рациону 20 г $\cdot$ гол $^{-1} \cdot$ сут $^{-1}$ премикса, содержащего 2 г биомассы спирулины (26), положительно влияло на физиологические и микробиологические процессы в рубце, поддерживая его нормальное состояние. При этом установлено усиление образования ЛЖК на 32,95 \% в начале и на 9,4 \% - в конце опыта, увеличение количества инфузорий на $37,7 \%$ в начале и на $11,29 \%$ - в конце опыта, также наблюдался рост обилия МАФанМ на 5,2 \%, лактобацилл на $6,9 \%$ по сравнению с контролем, что свидетельствует о пробиотических свойствах спирулины.

Эффективность применения биологически активных кормовых добавок зависит не только от их функциональных свойств, но и от дозировки. В частности, влияние шунгита на ферментативные и микробиологические процессы в рубце овец мы изучали при его добавлении в рацион в количестве $0,3,0,9$ и $1,5 \%$ от сухого вещества.

Включение в рацион минерала в дозе $0,3 \%$ от СВ не повлияло на $\mathrm{pH}$ химуса. При увеличении дозы в 3 и 5 раз наблюдалось незначительное повышение рН (на 3,5 \% по отношению к контрольному периоду) (табл. 4). Включение шунгита в рацион повысило содержание в химусе ЛЖК на 20,6; 27,2 $(\mathrm{p}<0,05)$ и 22,8 \% и снизило количество аммиака на 18,6 (p < 0,05), 12,6 
$(\mathrm{p}<0,05)$ и 8,5 \% по отношению к контрольной группе, в результате чего индекс аммиак/ЛЖК значительно снизился и составил 1,81; 1,85 и 1,99 при дозировках соответственно 0,3; 0,9 и $1,5 \%$, в то время как в контрольной группе он был равен 2,67. Все дозировки шунгита в равной степени оказали влияние на амилолитическую активность химуса, которая понизилась на 16,8-19,9\%. Изменения в бродильных процессах в химусе под влиянием шунгита адекватно отразились на микробиоте.

4. Физиолого-биохимические и микробиологические показатели химуса рубца у овец (Ovis aries) романовской породы при включении в рацион различных доз шунгита ( $n=3, M \pm \mathrm{SEM}$, ФГБНУ ФНЦ ВИЖ им. Л.К. Эрнста, 2014 год)

\begin{tabular}{|c|c|c|c|c|}
\hline \multirow{3}{*}{ Показатель } & \multicolumn{4}{|c|}{ Группа } \\
\hline & \multirow{2}{*}{ контроль } & \multicolumn{3}{|c|}{ опыт (шунгит, \% сухого вещества) } \\
\hline & & 0,3 & 0,9 & 1,5 \\
\hline $\mathrm{pH}$ & $5,7 \pm 0,39$ & $5,7 \pm 0,06$ & $5,9 \pm 0,09$ & $5,9 \pm 0,33$ \\
\hline ЛЖК, ммоль/100 мл & $9,2 \pm 0,43$ & $11,1 \pm 0,95$ & $11,7 \pm 0,36^{*}$ & $11,3 \pm 0,97$ \\
\hline Аммиак, мг\% & $24,7 \pm 0,46$ & $20,1 \pm 0,96^{*}$ & $21,6 \pm 0,53^{*}$ & $22,6 \pm 1,38$ \\
\hline Индекс аммиак/ЛЖК & 2,67 & 1,81 & 1,85 & 1,99 \\
\hline Амилолитическая активность, Е/мл & $22,6 \pm 1,38$ & $18,6 \pm 0,41$ & $18,8 \pm 0,40$ & $18,1 \pm 1,40$ \\
\hline \multicolumn{5}{|l|}{ Микроорганизмы, г/100 мл: } \\
\hline всего & $1,35 \pm 0,100$ & $2,70 \pm 0,280^{* *}$ & $1,99 \pm 0,540^{*}$ & $1,69 \pm 0,170$ \\
\hline \multicolumn{5}{|l|}{ в том числе } \\
\hline $\begin{array}{l}\text { инфузории, г/100 мл } \\
\text { инфузории, \% }\end{array}$ & $\begin{array}{l}0,93 \pm 0,090 \\
\quad 68,8\end{array}$ & $\begin{array}{l}2,03 \pm 0,110^{* *} \\
75,2\end{array}$ & $\begin{array}{l}1,57 \pm 0,500^{* *} \\
78.9\end{array}$ & $\begin{array}{l}0,92 \pm 0,040 \\
54.4\end{array}$ \\
\hline бактерии, г/100 мл & $0,42 \pm 0,060$ & $0,67 \pm 0,190$ & $0,42 \pm 0,080$ & $0,77 \pm 0,170$ \\
\hline бактерии, \% & 31,2 & 24,8 & 21,1 & 45,6 \\
\hline \multicolumn{5}{|c|}{$\begin{array}{l}\text { П р и м е ч а н и е. ЛЖК - летучие жирные кислоты. Подробное описание опытных групп см. в разделе } \\
\text { «Методика». } \\
\text { *, ** Различия с контролем статистически значимы соответственно при } p<0,05 \text { и } p<0,01 \text {. }\end{array}$} \\
\hline
\end{tabular}

Известно, что кислотность рубца - один из наиболее изменчивых факторов, который может воздействовать на микрофлору и продукцию ЛЖК. Бактерии, способные переваривать клетчатку, наиболее активны при кислотности среды в пределах рН 6,2-6,8. Для бактерий, гидролизующих крахмал, благоприятна более кислая среда с $\mathrm{pH}$ 5,4-6,2. Количество простейших может быть значительно снижено при $\mathrm{pH} 5,5$. Шунгит в рационе положительно влиял на обилие микрофлоры в рубце. Наибольшее увеличение (в 2 раза) наблюдалось при дозировке $0,3 \%$ СВ (p < 0,01). С повышением дозировки эффект снижался. Так, шунгит в дозах 0,9 и 1,5 \% СВ повышал количество микроорганизмов в рубце только на 47,4 (p < 0,05) и $25,2 \%$. При этом дозировки шунгита сказались и на видовом составе микробиоты. Увеличение общего количества микробиальной массы происходило в основном за счет инфузорий. Так, наблюдали достоверное повышение содержания инфузорий в рубце животных, получавших 0,3 и 0,9 \% шунгита к основному рациону, - соответственно более чем в 2 раза $(\mathrm{p}<0,01)$ и на $68,8 \%(\mathrm{p}<0,01)$. При $0,3 \%$ СВ соотношение инфузорий и бактерий составило 75,2 \% против 24,8\%, при 0,9 и $1,5 \%$ СВ - соответственно $78,9 \%$ против $21,1 \%$ и $54,4 \%$ против $45,6 \%$.

Продуктивность жвачных животных зависит от степени переваривания в рубце кормов рациона, структура и питательность которого значительно варьирует, что непосредственно влияет на процессы ферментации и формирование микробиоценоза. Ключевым фактором, благоприятствующим пищеварению в рубце, становится создание оптимальной для размножения микроорганизмов среды, которая характерна для уксуснокислого типа брожения (рН 6,6-6,9). Среди изученных нами кормовых добавок природного происхождения наиболее эффективными оказались ДКВ и спирулина. При их включении в рацион рН химуса повысился соответственно на 12,6 и 9,5\%, тогда как действие остальных КД было менее эффективным. 
В других исследованиях изучали последствия низкого рН в рубце для пищеварения, включая профили доступных ЛЖК (35). Чувствительность коров к подострому ацидозу исследовали на фоне высококонцентратного рациона, состоящего из $35 \%$ грубых и $65 \%$ концентрированных кормов (34), а также на фистулированных животных при использовании разных кормовых добавок (36). Кислотность в рубце изучали с помощью вживленного в ретикулум датчика. В результате был установлен широкий диапазон значения рН (от 5,05 до 6,98), что указывает на адаптацию и толерантность коров к ацидозу.

В исследованиях M.A.M. Abdullah с соавт. (37) оценивалось влияние стручков акации при их добавлении (1,5 и 3,0 \%) в корм овцам. Эти изменения в рационах не повлияли на $\mathrm{pH}$ рубцового содержимого, однако обилие простейших в рубце снизилось. Сообщалось, что образование и всасывание ЛЖК непосредственно связано с $\mathrm{pH}$ химуса. Низкий рН химуса замедлял процессы липолиза и гидролиза жирных кислот, что ассоциировалось с уменьшением количества ДНК бактерий $(38,39)$. По действию на образование ЛЖК в наших опытах наиболее эффективными были шунгит при всех дозировках и М-Са. При их включении в рацион увеличение содержания ЛЖК в химусе составило соответственно 20,6; 27,2 (p < 0,05), 22,8 и 6,6 \%. Действие ДКВ + ОІ, ДКВ и спирулины на образование ЛЖК было негативным (продукция на уровне 93,5; 81,2 и 81,8 \% от показателя в контрольный периоду). Включение в рацион всех изученных КД, за исключением сочетания ДКВ + OI, привело к уменьшению содержания в химусе аммиака (наибольшее - на 24,1 (p < 0,05) и 26,3 \% - произошло под влиянием ДКВ и М-Са). Шунгит также снижал содержание аммиака в химусе: по отношению к контрольному периоду оно составило 81,3; 87,45 и 91,5 \% для дозировок соответственно 0,3, 0,9 и 1,5\% СВ.

Аналогичные результаты были получены М.H. Ghaffari с соавт. (40) при замене сена люцерны в рационе овец побочными продуктами переработки. Концентрация аммиака снижалась при увеличении количества фисташковой шелухи, которая заменяла сено. При этом у подопытных овец не наблюдали различий в значениях $\mathrm{pH}$ в рубце (40). Отходы от переработки урожая финиковой пальмы (9, 18 и 27 \% от ОР) снижали концентрацию аммонийного азота в рубце и повышали синтез микробного белка, однако состав рациона не повлияния на $\mathrm{pH}$ среды (41). В наших опытах включение в рацион овец ДКВ + ОI привело к увеличению содержания аммиака в химусе на 16,5 \% по отношению к контрольному периоду, что, возможно, связано с усилением окислительных процессов и снижением образования ЛЖК под действием йода.

Эффекты изучаемых КД в отношении амилолитической активности химуса также различались. Ее повышение на 6,$1 ; 1,7$ и 1,1 \% отмечалось при применении соответственно спирулины, М-Са и ДКВ + ОІ. Под влиянием шунгита показатель значительно снижался $(17,7 ; 16,8$ и 19,9 \% от активности в контроле при дозировке соответственно 0,3; 0,9, 1,5 \% СВ). Под действием ДКВ это снижение было минимальным и составило 7,3\%.

Состояние ферментативных процессов и их изменения непосредственно отразились на микробиоте. Наибольшее увеличение микробной массы в химусе вызывал шунгит, но его эффект зависел от дозировки. При включении шунгита в рацион возросла общая численность микроорганизмов - по группам соответственно в 2 раза $(\mathrm{p}<0,01)$, на 47,4 \% (p < 0,05) и $25,2 \%$ по сравнению с контролем (в основном за счет инфузорий) - и изменилось соотношение инфузории/бактерии. С повышением доли шунгита в СВ рациона снижалось общее количество микроорганизмов и меня- 
лось процентное соотношение инфузорий и бактерий. ДКВ + OЈ, ДКВ и М-Са значительно меньше повлияли на прирост микробиальной массы в химусе, чем шунгит (показатели относительно контрольного периода повысились соответственно на 14,6; 2,2 и 1,8 \%). Под действием спирулины общее количества микроорганизмов снижалось на 14,3 \% за счет как инфузорий, так и бактерий.

При анализе влияния изученных нами КД на микробиоценоз рубца прослеживалась положительная связь с индексом отношения аммиак/ЛЖК, который характеризует степень конверсии корма в микробный протеин. Количество продуктов глюкогенной ферментации и образование микробного протеина в значительной степени зависят от скорости ферментации. Медленная ферментация субстратов снижает образование этих продуктов, повышает долю пропионовой кислоты и уменьшает - уксусной и масляной кислот $(42,43)$.

Ряд авторов также изучали возможность модуляции рубцовой микрофлоры в рубце овец и молодняка крупного рогатого скота с использованием биологически активных веществ (44-47). Использование фитиобиотических и минеральных компонентов в составе рациона жвачных способствовало усилению ферментативных и микробиальных процессов в рубце. Среди кормовых средств особое внимание уделяется морским водорослям, которые используются как пребиотики для повышения продуктивности и продуктивного здоровья животных. Включение водорослей в рацион животных улучшает экологию кишечника (48).

Итак, сравнительное изучение кормовых добавок природного происхождения - дигидрокверцетин, органический йод, мицеллат кальция, спирулину и шунгит, использованных в рационах овец, показало их специфическое действие на ферментативные и микробиологические процессы в рубце. В частности, дигидрокверцетин повышал $\mathrm{pH}$ и восстановительный потенциал содержимого рубца, стимулировал рост бактериальной массы; органический йод повышал рН и окислительный потенциал химуса, способствовал увеличению бактериальной массы; мицеллат кальция повышал pH и снижал восстановительный потенциал химуса; спирулина повышала pH химуса. Шунгит в дозах 0,3 и 0,9 \% сухого вещества рациона был более эффективен, чем в концентрации 1,5 \%, в отношении образования летучих жирных кислот и роста биомассы химуса. Результаты наших исследований могут быть использованы в практике кормления овец с целью модулирования функциональных свойств рационов. С учетом того, что при выборе кормовых добавок следует также учитывать их действие на метаболические процессы и формирование иммунитета животного, наиболее перспективными представляются дигидрокверцетин и шунгит.

\author{
ФГБНУ Федеральный научный центр \\ животноводства - ВИЖ им. академика Л.К. Эрнста, \\ 142132 Россия, Московская обл., г.о. Подольск, пос. Дубровицы, 60, \\ e-mail: urij.fomichev@yandex.ru,652202@mail.ru $\bowtie$, \\ romanoff-viktor51@yandex.ru, kolodin77@mail.ru \\ Поступила в редакцию \\ 7 апреля 2020 года \\ Sel'skokhozyaistvennaya biologiya [Agricultural Biology], 2020, V. 55, № 4, pp. 770-783

\section{COMPARATIVE ASSESSMENT OF NATURAL FEED ADDITIVES FOR FUNCTIONAL EFFECTS ON THE DIGESTIVE PROCESSES IN THE RUMEN OF SHEEP (Ovis aries)}

\author{
Yu.P. Fomichev, N.V. Bogolyubova, V.N. Romanov, E.N. Kolodina
}


Russia, e-mail urij.fomichev@yandex.ru,652202@mail.ru (corresponding author $ه$ ), romanoff-viktor51@yandex.ru, kolodin77@mail.ru

ORCID:

Fomichev Yu.P. orcid.org/0000-0003-0213-5526

Bogolyubova N.V. orcid.org/0000-0002-0520-7022

Romanov V.N. orcid.org/0000-0002-3542-5370

The authors declare no conflict of interests

Acknowledgements:

Supported financially from the Ministry of Education and Science of the Russian Federation within a support for fundamental research, state registration number NIOKR AAAA-A18-118021590136-7

Received April 7, 2020 doi: 10.15389 /agrobiology.2020.4.770eng

\section{Abstract}

In ruminant husbandry, ergotropics, fungal cultures, modifiers, antioxidants, enzymes, and other feed additives with various biological properties help practitioners to create optimal conditions for ruminal microorganisms to grow and to digest various feed substrates of the diet. This paper first compares functional effects of bioactive natural substances (dihydroquercetin, organic iodine, micellar calcium, spirulina, and shungite) on the rumen digestion in Romanov sheep. The work aimed to investigate the peculiarities of the influence of natural feed additives different in their biological properties on fermentative and microbiological processes in the rumen of sheep. Dietary trials were performed in the conditions of the physiological yard, the Ernst Federal Science Center for Animal Husbandry, with Romanov sheep (Ovis aries). In 2014, 12 animals aged 4-5 months were assigned to four dietary treatments: a basal diet without supplementation (BD, the control animals), $\mathrm{BD}+$ shungite $(0.3 \%$ dry matter $), \mathrm{BD}+$ shungite $(0.9 \%$ dry matter $)$, and $\mathrm{BD}+$ shungite $(1.5 \%$ dry matter $)$. In 2018-2019, six fistulated sheep aged 2 years were fed according to two schemes. The first scheme of dietary treatment was as follows: BD for equalization, BD (control), dihydroquercetin (DHQ) $\left(100 \mathrm{mg} \cdot\right.$ head $^{-1} \cdot$ day $\left.^{-1}\right)+$ organic iodine $(\mathrm{OI})\left(1.05 \mathrm{mg} \cdot\right.$ head $^{-1} \cdot$ day $\left.^{-1}\right)$, BD for equalization, and DHQ $\left(100 \mathrm{mg} \cdot\right.$ head $\left.^{-1} \cdot \mathrm{day}^{-1}\right)$, each period lasted 14 days. In the second scheme, micellar calcium (M-Ca) injected into the rumen through a fistula $\left(50 \mu \mathrm{l} \cdot\right.$ head $^{-1} \cdot$ day $\left.^{-1}\right)$ was used instead of DHQ + OI, and spirulina $\left(1.25 \mathrm{~g} \cdot \mathrm{head}^{-1} \cdot \mathrm{day}^{-1}\right.$, the dry powder mixed with $23.75 \mathrm{~g}$ filler) instead of DHQ. In all tests, at the end of each period, 3 hours after feeding, rumen contents were sampled to assess $\mathrm{pH}$, redox potential (ROP), oxidization, total amount of volatile fatty acids (VFA), concentration of ammonia nitrogen, amylolytic activity, the biomass of ruminal protozoa and bacteria, and the microbial profiles. It was found that DHQ and spirulina have the most pronounced effect on ruminal $\mathrm{pH}$, with a 12.7 and $9.5 \%$ increase in the chyme $\mathrm{pH}$, respectively. All dosages of shungite and $\mathrm{M}$-Ca provide higher production of volatile fatty acids (VFA), the 20.6; $27.2(\mathrm{p}<0.05), 22.8$ and $6.6 \%$ of the controls. DHQ + OI, DHQ and spirulina, in contrast, depress VFA production to 93.5, 81.2 and $81.8 \%$ levels of the controls. The dietary additives, except for DHQ + OI, decrease the chyme level of ammonia, which was the greatest for DHQ and M-Ca, by $24.1 \%$ at p $<0.01$ and $26.3 \%$, respectively. Shungite also depresses the chyme ammonia concentration by $18.7(\mathrm{p}<0.05), 14.9(\mathrm{p}<0.05)$ and $9.4 \%$ compared to the control. Dietary DHQ + OI, on the contrary, increases this indicator by $16.5 \%$. Dietary spirulina, M-Ca and DHQ + OI resulted in the 6.1, 1.7 and $1.1 \%$ increase in the chyme amylolytic activity, respectively, the dietary shungite causes its significant decrease, by $16.8-19.9 \%$, while the influence of DHQ is the least with a $7.3 \%$ decrease. It was shown that the rumen fermentation affects counts and species composition of the microbiota. The greatest increase in the chyme microbial biomass results from dietary shungite and depends on the mineral dosage. Dietary shungite increases the overall number of microorganisms 2 times $(\mathrm{p}<0.01)$, by $47.4 \%(\mathrm{p}<0.05)$ and $25.2 \%$, respectively, mainly due to infusoria, and changes the percentage ratio between infusoria and bacteria. DHQ + OI, DHQ and M-Ca also lead to an increase in the chyme microbial biomass but to a much lesser extent as compared to the shungite, i.e. to $14.6,2.2$ and $1.8 \%$ of the control, respectively. Dietary spirulina depresses the total number of microorganisms by $14.3 \%$. The study traces a positive relationship between the effects of the studied natural feed additives on the rumen microbiocenosis and the ammonia/VFA ratio of, which can characterize the rate of feed conversion to microbial protein.

Keywords: feed additives, shungite, dihydrouridine, organic iodine, spirulina, Romanov sheep, rumen, fermentation, chyme, amylase, volatile fatty acids, ammonia, microbiota.

\section{REFEREN C ES}

1. Russell J.B., Rychlik J.L. Factors that alter rumen microbial ecology. Science, 2001, 292(5519): 1119-1222 (doi: 10.1126/science.1058830).

2. Agarwal N., Kamra D.N., Chaudhary L.C. Rumen microbial ecosystem of domesticated ruminants. In: Rumen microbiology: from evolution to revolution. A. Puniya, R. Singh, D. Kamra (eds.). Springer, New Delhi. 2015 (doi: 10.1007/978-81-322-2401-3_2).

3. Russell J.B., Rychlik, J.L. Factors that alter rumen microbial ecology. Science, 2001, 292(5519): 1119-1122 (doi: 10.1126/science.1058830).

4. Krehbie C.R. Invited review: applied nutrition of ruminants: fermentation and digestive physiology. The Professional Animal Scientist, 2014, 30(2): 129-139 (doi: 10.15232/S1080-7446(15)30100-5). 
5. Chernyshev N.I., Panin I.G., Shumskii N.I., Grechishnikov V.V. Antipitatel'nye faktory kormov. Spravochnaya kniga [Anti-nutritional factors of feed]. Voronezh, 2013 (in Russ.).

6. Ward J. Probiotic yeast for optimal rumen balance. All About Feed, 2017, 25(8): 24-25.

7. Maksimov R.T. Veterinariya sel'skokhozyaistvennykh zhivotnykh, 2008, 3: 64-65 (in Russ.).

8. Bogolyubova N., Korotky V., Zenkin A., Ryzhov V., Buryakov N. Digestion and metabolism indices of sheep when using activated charcoal supplement. OnLine Journal of Biological Sciences, 2017, 17(2): 121-127 (doi: 10.3844/ojbsci.2017.121.127).

9. Artem'eva O.A., Pereselkova D.A., Fomichev Yu.P. Dihydroquercetin, the bioactive substance, to be used against pathogenic microorganisms as an alternative to antibiotics. Agricultural Biology [Sel'skokhozyaistvennaya biologiya], 2015, 50(4): $513-519 \quad$ (doi: 10.15389/agrobiology.2015.4.513eng).

10. Aliev M.M., Gulieva K.A. Vestnik APK Stavropol'ya, 2018, 1(29): 57-59 (in Russ.).

11. EFSA Panel on Dietetic Products, Nutrition and Allergies (NDA), Turck D., Bresson J.-L., Burlingame B., Dean T., Fairweather-Tait S., Heinonen M., Hirsch-Ernst K., Mangelsdorf I., McArdle H.J., Naska A., Neuhäuser-Berthold M., Nowicka G., Pentieva K., Sanz Y., Siani A., Sjodin A., Stern M., Tome D., Vinceti M., Willatts P., Engel K.-H., Marchelli R., Pöting A., Poulsen M., Schlatter J., Gelbmann W., Loveren H.V. Scientific opinion on taxifolin-rich extract from Dahurian Larch (Larix gmelinii). EFSA Journal, 2017, 15(2): 4682 (doi: 10.2903/j.efsa.2017.4682).

12. Fomichev Yu.P., Nikanova L.A., Dorozhkin V.I., Torshkov A.A., Romanenko A.A., Es'kov E.K., Semenova A.A., Gonotskii V.A., Dunaev A.V., Yaroshevich G.S., Lashin S.A., Stol'naya N.I. Digidrokvertsetin $i$ arabinogalaktan - prirodnye bioregulyatory: primenenie $v$ sel'skom khozyaistve $i$ pishchevoi promyshlennosti. Monografiya [Dihydroquercetin and arabinogalactan, the natural bioregulators: application in agriculture and food industry. Monograph]. Moscow, 2017 (in Russ.).

13. Aghwan Z.A., Sazili A.Q., Kadhim K.K., Alimon A.R., Goh Y.M., Adeyemi K.D. Effects of dietary supplementation of selenium and iodine on growth performance, carcass characteristics and histology of thyroid gland in goats. Animal Science Journal, 2015, 87(5): 690-696 (doi: 10.1111/asj.12484).

14. Aghwan Z.A, Sazili A.Q., Alimon A.R., Goh Y.M., Hilmi M.A. Blood haematology, serum thyroid hormones and glutathione peroxidase status in Kacang goats fed inorganic iodine and selenium supplemented diets. Asian-Australasian Journal of Animal Sciences, 2013, 26(11): 15771582 (doi: 10.5713/ajas.2013.13180).

15. Xu J., Liu X.-L., Yang X.-F., Guo H.-L., Zhao L.-N., Sun X.-F. Supplemental selenium alleviates the toxic effects of excessive iodine on thyroid. Biological Trace Element Research, 2011, 141: 110-118 (doi: 10.1007/s12011-010-8728-8).

16. Rakhmanin Yu.A., Stekhin A.A., Yakovleva G.V. Biofizika vody [Biophysics of water]. Moscow, 2016 (in Russ.).

17. Zatsepina O.V., Stekhin A.A., Yakovleva G.V., P'yanzina I.P. Gigiena i sanitariya, 2013, 5: $37-$ 39 (in Russ.).

18. Ametov A.S., Doskina E.V., Kapustina N.V. Endokrinologiya, 2016, 4(17): 65-72 (in Russ.)

19. Shibil'skis P. Aktivirovannaya voda [Activated water]. Available: https://water-ionizer.ru/usefulinformation/aktivirovannaya-voda. Accessed: 16.03.2019 (in Russ.).

20. Rekomendatsii po ispol'zovaniyu ionizirovannoi vody [Recommendations for the use of ionized water]. Available: $\quad$ https://akvalife.club/ru/rekomendatsii-po-primeneniyu-ionizirovannoj-vody.html. Accessed: 16.03.2019 (in Russ.).

21. Becker E.W. Microalgae for human and animal nutrition. In: Handbook of microalgal culture: applied phycology and biotechnology, second edition. Richmond A., Hu Q. (eds.). Blackwell Publishing Ltd., 2013 (doi: 10.1002/9781118567166.ch25).

22. Kedik S.A., Yartsev E.I., Gul'tyaeva N.V. Spirulina - pishcha XXI veka [Spirulina as a food of the XXI century]. Moscow, 2006 (in Russ.).

23. Kedik S.A., Yartsev E.I., Sakaeva I.V., Zhavoronok E.S., Panov A.V. Biofarmatsevticheskii zhurnal, 2011, 3(3): 3-10 (in Russ.).

24. Zaitsev V.V., Tarabrin V.V., Voishcheva E.A. Vestnik meditsinskogo instituta "REAVIZ": reabilitatsiya, vrach $i$ zdorov'e, 2011, 1: 17-21 (in Russ.).

25. Holman B.W.B., Malau-Adul A.E.O. Spirulinaas a livestock supplement and animal feed. Journal of Animal Physiology and Animal Nutrition, 2012, 97(4): 615-623 (doi: 10.1111/j.14390396.2012.01328.x).

26. Rimkus M., Simkus A., Syvys R., Birutis S. Dry powdery fodder additive, supplement or fodder containing algae spirulina platensis. WO/2010/106468 MKI3 A23K 1/00 2006.01, A23K 1/02 2006.01, C12N 1/12 2006.01. SPILA, UAB (LT). № PCT/IB2010/051039. Decl. 10.03.2010. Publ. 23.09.2010.

27. Vetrov S.I., Lenkova N.I., Gorbatkina I.E. Shungit. Rossiiskii mineral [Shungite. Russian mineral]. Moscow, 2011 (in Russ.).

28. Andrievsky G.B., Bruskov V.I., Tykhomyrov A.A., Gudkov S.V. Peculiarities of the antioxidant and radioprotective effects of hydrated C60 fullerene nanostructures in vitro and in vivo. Free Radical Biology and Medicine, 2009, 47(6): 786-793 (doi: 10.1016/j.freeradbiomed.2009.06.016).

29. Xiao Y., Wiesner M.R. Characterization of surface hydrophobicity of engineered nanoparticles. Journal of Hazardous Materials, 2012, 215-216: 146-151 (doi: 10.1016/j.jhazmat.2012.02.043). 
30. Zhang Y., Matsuo, Y., Li C.-Z., Tanaka H., Nakamura E. A scalable synthesis of methano[60]fullerene and congeners by the oxidative cyclopropanation reaction of silylmethylfullerene. Journal of the American Chemical Society, 2011, 133(21): 8086-8089 (doi: 10.1021/ja201267t).

31. Ponomarev A.P., Podkolzin I.V., Amelin V.G. Nanotekhnologii: nauka i proizvodstvo, 2012, 4(11): 48-55 (in Russ.).

32. Bogolyubova N.V., Romanov V.N., Devyatkin V.A., Kalinin Yu.K. Veterinariya i kormlenie, 2014, 5: 88-90 (in Russ.).

33. Tremasova A.M. Materialy nauchno-prakticheskoi konferentsii «Innovatsiya v sovremennoi farmakologii» [Proc. Conf. "Innovation in modern pharmacology”]. Kazan'-Moscow, 2012: 180181 (in Russ.).

34. Nasrollahi S.M., Zali A., Ghorbani G.R., Moradi S.M., Heydari S.A.M. Variability in susceptibility to acidosis among high producing mid-lactation dairy cows is associated with rumen $\mathrm{pH}$, fermentation, feed intake, sorting activity, and milk fat percentage. Animal Feed Science and Technology, 2017, 228: 72-82 (doi: 10.1016/j.anifeedsci.2017.03.007).

35. Dijkstra J., Ellis J.L., Kebread E., Strathe A.B., López S., France J., Bannink A. Ruminal pH regulation and nutritional consequences of low pH. Animal Feed Science and Technology, 2012, 172(1-2): 22-33 (doi: 10.1016/j.anifeedsci.2011.12.005).

36. Malekkhanhi M., Tahmasbi A.M., Naserian A.A., Danesh-Mesgaran M., Kleen J.L., AlZahal O., Ghaffari M.H. Effects of supplementation of active dried yeast and malate during subacute ruminal acidosis on rumen fermentation, microbial population, selected blood metabolites, and milk production in dairy cows. Animal Feed Science and technology, 2016, 213: 29-43 (doi: 10.1016/j.anifeedsci.2015.12.018).

37. Abdullah M.A.M., Farghaly M.M., Youssef I.M.I. Effect of feeding Acacia nilotica pods to sheep on nutrient digestibility, nitrogen balance, ruminal protozoa and rumen enzymes activity. Journal of Animal Physiology and Animal Nutrition, 2018, 102(3): 662-669 (doi: 10.1111/jpn.12874).

38. Benchaar C., McAllister T.A., Petit H.V., Chouinard P.Y. Whole flax seed and oil supplementation of dairy cows fed high-forage or high-concentrate diets: effect on digestion/ruminal fermentation characteristics, protozoal population and milk fatty acid profile. Animal Feed Science and technology, 2014, 198: 117-129 (doi: 10.1016/j.anifeedsci.2014.10.003).

39. Cone J.W., Becker P.M. Fermentation kinetics and production of volatile fatty acids and microbial protein by starchy feedstuffs. Animal Feed Science and technology, 2012, 172 (1-2): 3441 (doi: 10.1016/j.anifeedsci.2011.12.006).

40. Ghaffari M.H., Tahmasbi A.M., Khorvash M., Naserian A.-A., Ghaffari A. H., Valizadeh H. Effects of pistachio by-products in replacement of alfalfa hay on populations of rumen bacteria involved in biohydrogenation and fermentative parameters in the rumen of sheep. Journal of Animal Physiology and Animal Nutrition, 2013, 98(3): 578-586 (doi: 10.1111/jpn.12120).

41. Khezri A., Dayani O., Tahmasbi R. Effect of increasing levels of wasted date palm on digestion, rumen fermentation and microbial protein synthesis in sheep. Journal of Animal Physiology and Animal Nutrition, 2016, 101(1), 53-60 (doi: 10.1111/jpn.12504).

42. Ariko T., Kass M., Henno M., Fievez V., Kärt O., Kaart T., Ots M. The effect of replacing barley with glycerol in diet of dairy cows on rumen parameters and milk fatty acid profile. Animal Feed Science and Technology, 2015, 209: 69-78 (doi: 10.1016/j.anifeedsci.2015.08.004).

43. Qiao G.H., Zhou X.H., Li Y., Zhang H.S., Li J.H., Wang C.M., Lu Y. Effect of several supplemental Chinese herbs additives on rumen fermentation, antioxidant function and nutrient digestibility in sheep. Journal of Animal Physiology and Animal Nutrition, 2011, 96(5): 930-938 (doi: 10.1111/j.1439-0396.2011.01211.x).

44. Schofield B.J., Lachner N., Le O.T., McNeill D.M., Dart P., Ouwerkerk D., Hugenholtz P., Klieve A.V. Beneficial changes in rumen bacterial community profile in sheep and dairy calves as a result of feeding the probiotic Bacillus amyloliquefaciens H57. Journal of Applied Microbiology, 2018, 124(3): 855-866 (doi: 10.1111/jam.13688).

45. Bogolyubova N., Korotky V., Zenkin A., Romanov V., Ryzhov V. Assessing efficiency of the coniferous energy supplement in the diet of dairy cows for maintaining productive health. Asian Journal of Pharmaceutical and Clinical Research, 2017, 10(10): 117-120 (doi: 10.22159/ajpcr.2017.v10i10.19860).

46. Hosoda K., Matsuo M., Miyaji M., Matsuyama H., Maeda H., Ohta H., Kato H., Nonaka K. Fermentative quality of purple rice (Oryza sativa L.) silage and its effects on digestibility, ruminal fermentation and oxidative status markers in sheep: A preliminary study. Grassland Science, 2012, 58(3): 161-169 (doi: 10.1111/j.1744-697x.2012.00256.x).

47. Váradyová Z., Mravčáková D., Holodová M., Grešáková l'., Pisarčíková J., Barszcz M., Taciak M., Tuśnio A., Kišidayová S., Čobanová K. Modulation of ruminal and intestinal fermentation by medicinal plants and zinc from different sources. Journal of Animal Physiology and Animal Nutrition, 2018, 102(5): 1131-1145 (doi: 10.1111/jpn.12940).

48. Makkar H.P.S., Tran G., Heuze V., Giger-Reverdin S., Lessire M., Lebas F., Ankers P. Seaweeds for livestock diets: a review. Animal Feed Science and Technology, 2016, 212: 1-17 (doi: 10.1016/j.anifeedsci.2015.09.018). 